\title{
Sustainable Production Practices
}

\section{Adopted by Greenhouse and Nursery Plant Growers}

\author{
Jennifer H. Dennis ${ }^{1}$ \\ Department of Horticulture and Landscape Architecture and Department \\ of Agricultural Economics, Purdue University, West Lafayette, IN 47907
}

\author{
Roberto G. Lopez ${ }^{2,7}$ \\ Department of Horticulture and Landscape Architecture, Purdue University, \\ West Lafayette, IN 47907 \\ Bridget K. Behe ${ }^{3}$ \\ Department of Horticulture, Michigan State University, East Lansing, MI \\ 48824
}

\author{
Charles R. Hall ${ }^{3,4}$ \\ Department of Horticultural Sciences, Texas A\&M University, College \\ Station, TX 77843
}

\author{
Chengyan Yue ${ }^{2,5}$ \\ Department of Horticultural Science and Department of Applied Economics, \\ University of Minnesota, St. Paul, MN 55108
}

\section{Benjamin L. Campbell ${ }^{6}$}

Vineland Research and Innovation Centre, 4890 Victoria Avenue North, P.O Box 4000, Vineland Station, Ontario, Canada LOR 2E0

Additional index words. certification, floriculture, green industry, producer, survey

\begin{abstract}
Given recent consumer and market interest in more sustainable products and business practices, researchers conducted a nationwide survey of greenhouse and nursery crop growers to determine the current state of the industry in terms of sustainability. Growers were asked about the importance of sustainability, their views of state environmental regulations, sustainable practices in place and ones they would like to implement in the next 1 to 3 years, and interest in sustainable certification. None of the grower respondents in this survey were certified sustainable, but at least one fourth $\mathbf{( 2 5 . 8 \% )}$ were interested in certification. More than half of the respondents currently recycle plastic pots, use controlled-release fertilizers, and composted plant waste. However, only $12 \%$ of growers want to use biodegradable plant containers or implement water conservation measures into their production system within the next 1 to 3 years. Grower respondents felt the biggest obstacle toward implementation was the sustainable production practice would not be compatible with their existing system of production.
\end{abstract}

The $\$ 147.8$ billion U.S. green industry includes nursery and greenhouse producers, landscape service providers as well as whole-

Received for publication 3 May 2010. Accepted for publication 11 June 2010.

We gratefully acknowledge funding from the American Floral Endowment (AFE), the Horticultural Research Institute (HRI), and the Federal-State Marketing Improvement Program (FSMIP) that were instrumental in conducting this research effort. ${ }^{1}$ Associate Professor.

${ }^{2}$ Assistant Professor.

${ }^{3}$ Professor.

${ }^{4}$ Ellison Chair in International Floriculture.

${ }^{5}$ Bachman Endowed Chair in Horticultural Marketing.

${ }^{6}$ Principal Investigator.

${ }^{7}$ To whom reprint requests should be addressed; e-mailrglopez@purdue.edu.
Commercial greenhouse floriculture and nursery production is high-intensity and high-input agriculture that is often concentrated in or near urban centers making its production and waste disposal practices visible to the non-farm public (Berghage et al., 1999). To produce high-quality, uniform, and consistent crops, both industries frequently irrigate and fertilize their crops, which has led to ground and surface water contamination (Richards and Reed, 2004). They also rely heavily on insecticides, fungicides, growth regulators, and plastics (Berghage et al., 1999; Cameron, 2009; Krug et al., 2008; Lopez et al., 2008). For example, pots, flats, and cell packs produced for the nursery and greenhouse industries use an estimated 320 to $408 \mathrm{mn}$ pounds of plastic annually (Botts, 2007; Garthe and Kowal, 1993). Containers are disposed of by growers, consumers, and landscapers, thus presenting a significant disposal issue for the industry (Evans and Hensley, 2004).

Hodges et al. (2008) reported production practices of 2484 U.S. nursery firms as of 2005. Although sustainable production practices were not explicitly asked, several questions indicated some early adoption of them, especially for pest management decisions. One-third to one-half reported using pestresistant varieties. Eight percent to $27.2 \%$ used biopesticides or lower-toxicity pesticides. One-fourth to half adjusted fertilization rates based on environmental and plant factors or managed irrigation to reduce pests. Over half inspected incoming stock plants or removed infested plants or plant parts. So, there was evidence that some businesses were making environmentally friendly choices.

Consumer and market interest in nonhorticultural sustainable business practices has encouraged discussions about sustainable production and certification in the floriculture industry (Krug et al., 2008; Stewart, 2007). The goal of sustainable production is to reduce environmental degradation, maintain agricultural productivity, promote economic viability, conserve resources and energy, and maintain stable communities and quality of life (Krug et al., 2008). Examples of sustainable practices include, but are not limited to, recycling irrigation water and plastic, implementing biological controls, and using alternative energy sources (Lopez et al., 2008). Sustainable business practices are developed based on the economical use of resource inputs as well as how excesses or wastes are created and disposed. Many businesses already engage in sustainable business practices (e.g., water, electricity, or other fuel conservation or reduction of use) without characterizing the practice as sustainable.

In the United States, sustainable certification programs for floriculture products are very recent; the Veriflora ${ }^{\circledR}$ certification program began in 2007 and Milieu Project Sierteelt (MPS) certified their first U.S. operation in 2009 (Milieu Project Sierteelt, 2009; Veriflora 2009). Veriflora ${ }^{\circledR}$ and MPS offer similar services to customers but differ in their certification processes. Located in the 
United States, the Veriflora ${ }^{\circledR}$ certification program is for growers and handlers of freshcut flowers and potted plants. Based in The Netherlands, MPS targets entrepreneurs in the floriculture, bulb, nursery stock, and vegetable sectors (Milieu Project Sierteelt, 2009). The number of businesses that are adopting sustainable practices outside of these certification programs is unknown. Thus, there may be a substantial number of growers who engage in sustainable practices without the cost in time and money of certification.

The steps taken by the grower to become certified and how the growers are evaluated on their sustainable practices also differ between Veriflora ${ }^{\circledR}$ and MPS. Veriflora ${ }^{\circledR}$ focuses on eight categories for certification: sustainable crop production, ecosystem management and protection, resource conservation and energy efficiency, integrated waste management, fair labor practices, community benefits, product quality, and product safety and purity (Veriflora, 2009). MPS' approach to certification is based on four categories: crop protection agents, waste, energy, and fertilizers (Milieu Project Sierteelt, 2009). MPS' approach evaluates the production aspect of the business, whereas Veriflora ${ }^{\circledR}$ also examines the treatment of workers and the business' impact on the community.

Like with any shift in production, a change to a new technology may create a new segment of the market, thus creating a niche market for products or the entire output of that business. There is growing concern by consumers about the origin of products they purchase and how they were produced; as noted in previous research, some consumers are willing to pay a premium price or shop exclusively at one business over another if they know that products are grown locally or in a sustainable way (Krug et al., 2008). There also is a belief that the demand for organic and sustainable flower products is increasing in the United States as a result of an emerging market segment focused on health and fitness, the environment, personal development, sustainable living, and social justice, known as Lifestyles of Health and Sustainability (LOHAS) (Lifestyles of Health and Sustainability, 2009; Stewart, 2007). The LOHAS market represents $30 \%$ of all U.S. households and is spending \$230 billion annually on socially and environmentally responsible products (Stewart, 2007). Thus, the consumer demand for product stewardship or environmentally conscious products and business practices is rapidly rising.

Researchers recently investigated consumer preferences for some sustainable horticultural products and practices (Hall et al., 2010a; Yue et al., 2010). Consumers responded that one important attribute in a plant purchase was the container, but there was diversity in container preferences with some segments preferring compostable containers and others preferring containers made from recycled materials. One segment, labeled "Price Conscious," was more concerned about price than container type. As the number of consumers concerned about sustain- able business or production practices (among them type of plant container) increases, the demand for sustainable business practices may become greater.

The objectives of this study were 1) to create a benchmark of current sustainable production practices of greenhouse and nursery producers; and 2) to determine if differences exist based on attitudes and obstacles by income, grower type, and business classification. Benchmarks would provide future reference points to show adoption of sustainable methods.

By examining producer differences, marketers and suppliers may have a better idea of which growers would be more likely to adopt the newer methods and what impediments leads businesses not to adopt.

\section{Materials and Methods}

The population lists for all U.S. states were assembled from the respective Department of Agriculture offices responsible for licensing greenhouse and nursery producers. A master file of all certified operations was compiled at the University of Florida. Sample selection in each state was based on that state's proportion of the greenhouse and nursery population list. Stratified samples were drawn from all 50 states participating in the study based on the number of firms in different size categories in each state. Following the protocol from earlier industry surveys (Brooker et al., 2005), greenhouses and nurseries were grouped as very small (less than 1 acre), small (1 to 4.9 acres), medium (5 to 19.9 acres), or large (20 or more acres) based on acreage. Based on budgetary considerations and sample size necessary from a statistical perspective, the decision was made to draw a sample of $\approx 1000$ firms. Of these, $7.3 \%$ were large firms with the rest of the sample drawn from medium, small, and very small firms $(12.5 \%, 24.6 \%$, and $23.3 \%$, respectively). A total of $32.3 \%$ of the sample firms were unclassified in terms of size.

The survey instrument was adapted from an earlier study conducted by Hall et al. (2009). The questionnaire was developed by the researchers and included: one Likert scale on sustainable attitudes, one rank order on obstacles to adopting sustainable practices, two percentage-based questions on current and future practices as well as container types used, and 10 open-ended questions based on demographic and industry priorities. It asked respondents about the importance of sustainability, views of state environmental regulations, sustainable practices in place, sustainable practices they would like to implement in the future, and interest in sustainable certification. Questions concerning their attitudes and perceptions toward profitability, risk, and obstacles to adoption were also asked. Respondents were asked to report their square footage, gross sales, number of employees, crops grown, customer groups, and zip code. The survey instruments were approved by the Institutional Review Boards of the cooperating universities.
Researchers adapted the best practices of mail survey research as outlined in Dillman (2007). Survey copying and distribution were conducted by a local mailing service firm in Texas. A letter explaining the purpose of the survey with informed consent was included with the questionnaire. One week after the initial distribution of the questionnaire, a postcard was mailed to the entire sample as a reminder to return a completed form. A second questionnaire with a consent form and a second encouragement letter was mailed to non-respondents $\approx 3$ weeks after the first mailing. Researchers distributed 1000 surveys and 120 survey responses were collected for a response rate of $12 \%$. No incentives were given for completing the survey. All completed questionnaires were returned to Texas A\&M University for data entry. An analysis of variance was performed using SPSS 16.0 (SPSS Inc., Chicago, IL). Descriptions for each variable can be found in Table 1 .

\section{Results}

Demographic characteristics of growers and operations. Florida (16.8\%) had the highest percentage of survey returns followed by California (10.4\%), Pennsylvania (8.8\%), North Carolina $(8.9 \%)$, Texas $(5.6 \%)$, and New York (5.6\%), thus showing appropriate representation from key production areas. Survey respondents' average total square footage and covered production area were 515,822 and 120,536 square feet, respectively (Table 2). The average uncovered production area was $474,674 \mathrm{sq}$. ft. Respondents reported 14.7 full-time employees during the peak season and 14.5 part-time employees. This was slightly higher than 9.9 permanent and 8.9 temporary employees reported by 2485 U.S. green industry production firms in 2005 (Hodges et al., 2008). Just under half $(46.6 \%)$ of respondents reported gross income $\$ 99,999$ or less with the second largest category $(14.4 \%)$ reported as gross sales between $\$ 100,000$ and $\$ 249,999$ showing a large portion of green industry businesses were small based on income (Table 2). This was also consistent with Hodges et al. (2008). The majority of the green industry businesses surveyed classified themselves as growing shrubs and woody ornamentals $(36.8 \%)$ followed by container perennials (14.8\%) (Table 2). Based on income reported, the largest percentage of sales by customer group was for cash and carry customers $(34.3 \%)$ followed by landscape service providers $(18.1 \%)$. Survey respondents were equally classified as retailers $(22.4 \%)$, wholesalers $(18.4 \%)$, growers $(22.4 \%)$, or some combination $(28.8 \%$ ) (Table 2).

Sustainability. We asked respondents about their views of sustainability, practices used in their businesses, and practices they wanted to implement in the future. Most survey respondents stated the two most common definitions of sustainability were "minimal or no negative impact on the environment" as well as "going green" as it related to conservation of water, land, and resources (data 
Table 1. Description of attitudinal and obstacle variables used in a survey of green industry growers conducted in 2009 .

\begin{tabular}{|c|c|c|}
\hline Variable & Description & Measurement \\
\hline Water & The amount of water used by our business is a concern to the company & $1=$ strongly disagree $5=$ strongly agree \\
\hline Plastic & The amount of plastic used by our firm is a concern to the company & $1=$ strongly disagree $5=$ strongly agree \\
\hline Syn fert & The amount of synthetic fertilizers used by our business is a concern to the company & $1=$ strongly disagree $5=$ strongly agree \\
\hline Energy & The amount of energy used by our company is a concern to the business & $1=$ strongly disagree $5=$ strongly agree \\
\hline Resources & $\begin{array}{l}\text { Compared with other industries, the horticulture industry is a large consumer of natural } \\
\text { resources such as petroleum, fossil fuels, water, land, peat, etc. }\end{array}$ & $1=$ strongly disagree $5=$ strongly agree \\
\hline Strict water & My state has strict water regulations that affect my company's production practices & $1=$ strongly disagree $5=$ strongly agree \\
\hline Comp water & My state has more strict water regulations compared with other states & $1=$ strongly disagree $5=$ strongly agree \\
\hline Value sust & People in my company value sustainable horticulture production practices & $1=$ strongly disagree $5=$ strongly agree \\
\hline Cust value & Our customers value sustainable horticulture production practices & $1=$ strongly disagree $5=$ strongly agree \\
\hline Cust prded & Our customers care about how our products are produced & $1=$ strongly disagree $5=$ strongly agree \\
\hline Sust wrth & Implementing sustainable practices is a worthwhile investment & $1=$ strongly disagree $5=$ strongly agree \\
\hline Profits & Becoming a more sustainable business will generate more profits for the company & $1=$ strongly disagree $5=$ strongly agree \\
\hline Mngmt sust & Our management encourages employees to suggest new sustainable production practices & $1=$ strongly disagree $5=$ strongly agree \\
\hline Uncertain & Uncertainty of how to implement sustainable horticulture practices & $1=$ small obstacle $10=$ big obstacle \\
\hline Knowld envir & Insufficient knowledge of potential effects of sustainable practices on the environment & $1=$ small obstacle $10=$ big obstacle \\
\hline Financial & Insufficient knowledge of potential financial effects of sustainable practices on the business & $1=$ small obstacle $10=$ big obstacle \\
\hline Compatible & New production practices not compatible with existing system of production & $1=$ small obstacle $10=$ big obstacle \\
\hline Unce prft & Uncertainty of profitability from conversion to sustainable production practices & $1=$ small obstacle $10=$ big obstacle \\
\hline Cash flow & Inadequate cash flow (financing) to change to more sustainable production practices & $1=$ small obstacle $10=$ big obstacle \\
\hline Cust sust & Customers do not value sustainable production practices & $1=$ small obstacle $10=$ big obstacle \\
\hline Incentive & $\begin{array}{l}\text { Little incentive (tax credit, federal grants) to the grower to convert to sustainable } \\
\text { horticulture practices }\end{array}$ & $1=$ small obstacle $10=$ big obstacle \\
\hline Loss & Potential loss too big of a risk in the conversion process & $1=$ small obstacle $10=$ big obstacle \\
\hline
\end{tabular}

not shown). Respondents were asked to indicate from a list of sustainable production practices that were already implemented in their operations. The highest sustainable categories were: recycling plastic pots $(69.6 \%)$, use of controlled-release fertilizer $(66.4 \%)$, composting plant waste $(64.0 \%)$, conservation/ efficiency of energy $(55.2 \%)$, use of biological pest controls $(44.0 \%)$, water conservation measures $(44.0 \%)$, and use of organic fertilizers $(41.6 \%)$ (Table 3). Survey respondents were also asked which practices their companies planned to implement in 1 to 3 years. The highest sustainable categories for future implementation were: biodegradable plant containers $(12.0 \%)$, irrigation water conservation measures (12.0\%), wind as an alternative/supplemental energy source $(9.6 \%)$, and sun as an alternative/supplemental energy source $(9.6 \%)$ (Table 2). All of the respondents stated their operation was not certified sustainable; however, at least onefourth $(25.8 \%)$ were interested in becoming certified (data not shown).

Containers. We asked respondents to identify the type of containers used (virgin plastic, recycled plastic, rice hull, polylactic acid (PLA), or cornstarch or wheat starch, peat, coir, and other) in their operations and a majority $(74.4 \%)$ reported recycled plastic followed by virgin plastic $(48.8 \%)$ and peat $(12.8 \%)$ (data not shown). We also asked green industry businesses the percentage of all containers used in 2009. Although less than one-fourth use recycled plastic, those that used it stated it accounted for just under half $(49.8 \%)$ of all container types used. Virgin plastic had the second highest percentage at $25.5 \%$. Peat containers accounted for $2.6 \%$ of container type used.

Opinions about sustainability. We asked respondents to state how they felt about sustainability using a 5-point Likert scale with $1=$ "strongly disagree" and $5=$ "strongly agree." Overall, respondents were neutral in most statements but had the highest rating (3.9) regarding "people in my company value sustainable horticulture practices." Respondents had the lowest rating (2.6) regarding "my state has strict water regulations that affect my company's production practices."

We also asked their biggest obstacles that would affect the adoption of sustainable production practices. On a scale of $1=$ "small obstacle" to $10=$ "biggest obstacle," respondents rated other factors such as unavailability of biodegradable pots and the economy as the biggest obstacles (8.0) followed by inadequate financing to change to sustainable production practices (7.0) and little incentive to growers to convert to sustainable practices (6.8). The smallest obstacle was based on customers not valuing sustainability (4.6).

Comparisons by percentage crop grown. We asked respondents to identify the percentage of crops grown in their operations, which was later categorized into four categories: nursery only, greenhouse only, greenhouse/nursery, and other types of growers. There was a significant difference in three attitudinal and two obstacle variables among grower types (Table 4). The variable "energy," which stated that the amount of energy used by their operation was a concern to the business was statistically significant ( $P=$ 0.09 ) by grower type. The "greenhouse only" group (2.6) was different compared with the "greenhouse/nursery" (3.8) and "other" (4.0) group. Growers' attitudes toward the variable "comp water," which compared water restrictions from their state to other states, was statistically significant $(P=0.03)$ showing mean differences were statistically lower in the "greenhouse/nursery" group (2.4) than in the "nursery only" (3.0), "greenhouse only" (3.0), and "other" (3.3) categories. Growers had varying attitudes toward "cust prdcd," which asked whether customers cared about how products were produced. "Cust prdcd" was statistically significant $(P=0.08)$ showing the "other" group was almost neutral (2.9) in their attitude and was different from the "greenhouse only" (4.3) group that agreed with the statement. Only two variables based on obstacles were significantly different based on grower groups. The "financial" variable was significant $(P=0.07)$ and rated as a higher obstacle for the "greenhouse/nursery" group (5.9) than the "nursery only" (4.7), "greenhouse only" (6.8), and "other" (6.8) groups. "Compatible" was also significant $(P=0.03)$ showing a range of differences between groups (Table 4). The "greenhouse only" group thought non-compatibility of production systems was a small obstacle (1.5) compared with the "other" group (6.2).

Comparisons by business classification. Finally, growers were asked to classify themselves as retailers, wholesalers, or growers. Four categories were created based on their percentage allocation into retailers only, wholesaler only, grower only, and combined. Results show there were statistical differences between groups for four attitudinal variables and one obstacle. "Energy" was different for "retailers" (3.2) and "growers" (4.0) (Table 5). Attitudes about "resources" were also different based on business classification for the "wholesaler" (2.5) and "retailer only" (3.4) category. "Retailers" had the most positive response (4.2) to the variable "sust wrth" but differed statistically from the wholesaler only group (3.5). Attitudes by group were also significant for the variable "profits" $(P=0.08)$, which differed statistically between the "retailer" and "wholesaler group." "Wholesalers" saw "cust sust" as a bigger obstacle than "retailers" $(P=0.00)$ stating it was the biggest obstacle (6.3), whereas the "retailer" group stated it was a small obstacle (3.2). 
Table 2. Demographic characteristics of the green industry respondents' operation.

\begin{tabular}{|c|c|c|}
\hline & Number of respondents & $(\%)$ \\
\hline \multicolumn{3}{|l|}{ Size (gross sales) } \\
\hline$\$ 99,999$ or less & 58 & 46.4 \\
\hline$\$ 100,000-249,999$ & 18 & 14.4 \\
\hline$\$ 250,001-499,999$ & 13 & 10.4 \\
\hline$\$ 500,001-999,999$ & 11 & 8.8 \\
\hline$\$ 1,000,001-4,999,999$ & 13 & 10.4 \\
\hline$\$ 5,000,001-9,999,999$ & 0 & 0.0 \\
\hline$\$ 10,000,000$ or greater & 3 & 2.4 \\
\hline \multirow[t]{2}{*}{ Did not respond } & 9 & 7.2 \\
\hline & Mean & SD \\
\hline \multicolumn{3}{|l|}{ Size (square footage) } \\
\hline Total square footage & 515,822 & $1,229,954$ \\
\hline Covered greenhouse & 120,536 & 655,553 \\
\hline Uncovered production area & 474,674 & $1,113,668$ \\
\hline \multicolumn{3}{|l|}{ Employees (number of employees) } \\
\hline Full-time & 14.7 & 73.9 \\
\hline \multirow[t]{2}{*}{ Part-time } & 14.5 & 52.4 \\
\hline & Number of respondents & $(\%)$ \\
\hline \multicolumn{3}{|l|}{ Operation type } \\
\hline Retailer & 28 & 22.4 \\
\hline Wholesaler & 23 & 18.4 \\
\hline Grower & 28 & 22.4 \\
\hline Combined & 36 & 28.8 \\
\hline Did not respond & 10 & 8.0 \\
\hline Customer type $(\%)^{z}$ & Mean & SD \\
\hline Mass merchandiser & 1.9 & 12.5 \\
\hline Supermarket chains & 0.12 & 1.3 \\
\hline Wholesale retailers & 14.7 & 29.4 \\
\hline Landscape service providers & 18.1 & 30.9 \\
\hline Brokers & 1.5 & 6.5 \\
\hline Retail florists & 1.7 & 10.3 \\
\hline Other growers & 8.4 & 24.5 \\
\hline Cash and carry & 34.3 & 41.5 \\
\hline Others & 13.1 & 31.2 \\
\hline \multirow[t]{2}{*}{ Did not respond } & 6.2 & \\
\hline & Mean & SD \\
\hline \multicolumn{3}{|l|}{ Crops grown $(\%)^{z}$} \\
\hline Bedding plants & 10.9 & 22.2 \\
\hline Container perennials & 14.8 & 23.8 \\
\hline Flowering potted plants & 8.1 & 18.6 \\
\hline Potted foliage & 4.7 & 17.9 \\
\hline Fresh cut flowers & 1.7 & 10.9 \\
\hline Shrubs and woody ornamentals & 36.8 & 41.9 \\
\hline Plugs, liners, and propagation & 6.5 & 21.1 \\
\hline Herbs & 2.4 & 7.2 \\
\hline Vegetables & 3.8 & 9.4 \\
\hline Other & 6.1 & 22.3 \\
\hline Did not respond & 4.2 & \\
\hline
\end{tabular}

${ }^{\mathrm{z}}$ Growers ranked all categories that applied to the operation.

\section{Discussion}

Although resource conservation business decisions and production practices have been documented to some extent (e.g., Hall et al., 2009; Hodges et al., 2008), this study provides a benchmark of views related to sustainability in the commercial green industry by documenting the degree to which growers use sustainable practices. Results showed nursery and greenhouse respondents were predominately smaller growers; $80 \%$ had less than $\$ 1$ million in gross sales and mostly served landscape service providers and cash and carry customers. Most respondents indicated that sustainability in the green industry is about environmental stewardship. These results are consistent with Hall et al. (2009), which indicated that $65 \%$ of floriculture grower respondents thought sustainability was very important to the environment. However, from our results, greenhouses and nurseries are slowly implementing sustainable practices in their quest to become environmental stewards (Table 3). From this research and that of Hall et al. (2009) it is apparent that few green industry producers have implemented sustainable growing practices beyond composting, recycling, using biological controls, and conserving energy.

Few studies have been conducted to determine the performance and durability of biodegradable pots in the greenhouse, nursery, or retail setting. Hall et al. (2009), and this study found that less than $25 \%$ of respondents had biodegradable pots as part of their production system and fewer than $15 \%$ were going to implement them in the next 1 to 3 years. This low adoption rate suggests that grower concerns may affect adoption and is shown by a previous study (Hall et al., 2009) that suggests growers' concern about implementation and risk of converting to a new production technology such as biodegradable pots affects their adoption. Our study confirms the concern among growers that the implementation of a new sustainable production

Table 3. Responses of green industry growers' current and future sustainable production practices by percentage.

\begin{tabular}{|c|c|c|}
\hline Sustainable practice & Currently in place ${ }^{\mathrm{z}}(\%)$ & Would like to implement ${ }^{\mathrm{y}}(\%)$ \\
\hline Geothermal as an alternative/supplemental energy source & 5.6 & 6.4 \\
\hline Biological pest controls & 44.0 & 7.2 \\
\hline Chemical runoff protection (runoff retention ponds, remediation) & 25.6 & 3.2 \\
\hline Composting plant waste & 64.0 & 5.6 \\
\hline Conservation/efficiency of energy & 55.2 & 8.0 \\
\hline Use of controlled-release fertilizer & 66.4 & 7.2 \\
\hline Use of organic fertilizer & 41.6 & 3.2 \\
\hline Use of certified organic media & 15.2 & 4.8 \\
\hline Use of waste products in growing/production media (rice hulls, $\mathrm{PBH}$ rice hulls, etc.) & 22.4 & 3.2 \\
\hline Recycling plastic pots & 69.6 & 8.0 \\
\hline Use of containers made of alternative materials (cornstarch, rice hulls, etc.) & 4.8 & 7.2 \\
\hline Recycling plastic greenhouse coverings/glazings & 30.4 & 8.0 \\
\hline
\end{tabular}

${ }^{2}$ Growers were asked to indicate all sustainable practices that they had in place.

${ }^{\mathrm{y}}$ Growers were asked to indicate all sustainable practices they want to implement in 1 to 3 years. 
Table 4. Averages of green industry respondents' attitudes and obstacles regarding sustainability $(1=$ strongly disagree and $5=$ strongly agree, $1=$ small obstacle and $10=$ biggest obstacle) by crops grown.

\begin{tabular}{|c|c|c|c|c|}
\hline & Nursery only & Greenhouse only & Greenhouse/nursery & Other \\
\hline \multicolumn{5}{|l|}{ Attitudes } \\
\hline Water & 3.8 & 4.0 & 3.4 & 3.7 \\
\hline Plastic & 3.4 & 3.8 & 3.6 & 2.7 \\
\hline Syn fert & 3.2 & 2.4 & 3.3 & 2.7 \\
\hline Energy* & $3.7 \mathrm{ab}^{\mathrm{z}}$ & $2.6 \mathrm{~b}$ & $3.8 \mathrm{a}$ & $4.0 \mathrm{a}$ \\
\hline Resources & 2.9 & 2.4 & 3.0 & 2.7 \\
\hline Strict water & 2.8 & 2.8 & 2.3 & 2.8 \\
\hline Comp water** & $3.0 \mathrm{a}$ & $3.0 \mathrm{a}$ & $2.4 \mathrm{~b}$ & $3.3 \mathrm{a}$ \\
\hline Value sust & 4.0 & 4.3 & 3.8 & 3.6 \\
\hline Cust value & 3.6 & 4.0 & 3.2 & 3.0 \\
\hline Cust prded* & $3.4 \mathrm{ab}$ & $4.3 \mathrm{a}$ & $3.3 \mathrm{ab}$ & $2.9 \mathrm{~b}$ \\
\hline Sust wrth & 3.8 & 4.3 & 3.8 & 3.6 \\
\hline Profits & 3.4 & 3.5 & 3.2 & 3.2 \\
\hline Mngmt sust & 3.7 & 3.3 & 3.5 & 3.2 \\
\hline \multicolumn{5}{|l|}{ Obstacles } \\
\hline Uncertain & 4.9 & 5.5 & 5.1 & 6.9 \\
\hline Knowld envir & 4.6 & 5.5 & 4.3 & 6.8 \\
\hline Financial* & $4.7 \mathrm{a}$ & $6.8 \mathrm{a}$ & $5.9 \mathrm{~b}$ & $6.8 \mathrm{a}$ \\
\hline Compatible** & $4.1 \mathrm{ab}$ & $1.5 \mathrm{~b}$ & $5.2 \mathrm{ab}$ & $6.2 \mathrm{a}$ \\
\hline Unce prft & 5.3 & 4.8 & 6.1 & 5.5 \\
\hline Cash flow & 6.4 & 7.0 & 7.6 & 5.8 \\
\hline Cust sust & 4.7 & 4.3 & 4.6 & 4.9 \\
\hline Incentive & 6.5 & 8.8 & 6.4 & 6.2 \\
\hline Loss & 4.9 & 4.5 & 6.1 & 5.7 \\
\hline
\end{tabular}

${ }^{2}$ Within-row means followed by different letters are significantly different by Tukey's honestly significant difference test at $P \leq 0.05$.

*Significant at the $P=0.10$ level, **significant at the $P=0.05$ level, ***significant at the $P=0.01$ level.

Table 5. Averages of green industry respondents' attitudes and obstacles regarding sustainability $(1=$ strongly disagree and $5=$ strongly agree, $1=$ small obstacle and $10=$ biggest obstacle) by business classification.

\begin{tabular}{|c|c|c|c|c|}
\hline & Retailer only & Wholesaler only & Grower only & Combined \\
\hline \multicolumn{5}{|l|}{ Attitudes } \\
\hline Water & 3.4 & 3.9 & 3.7 & 3.6 \\
\hline Plastic & 3.5 & 3.5 & 3.4 & 3.7 \\
\hline Syn fert & 3.1 & 3.0 & 3.2 & 3.5 \\
\hline Energy* & $3.2 \mathrm{~b}^{\mathrm{z}}$ & $3.7 \mathrm{ab}$ & $4.0 \mathrm{a}$ & $3.9 \mathrm{ab}$ \\
\hline Resources** & $3.4 \mathrm{a}$ & $2.5 \mathrm{a}$ & $3.1 \mathrm{ab}$ & $2.9 \mathrm{ab}$ \\
\hline Strict water & 2.3 & 2.7 & 2.8 & 2.4 \\
\hline Comp water & 2.4 & 3.1 & 2.7 & 2.6 \\
\hline Value sust & 4.0 & 3.6 & 3.8 & 3.9 \\
\hline Cust value & 3.5 & 3.2 & 3.2 & 3.5 \\
\hline Cust prded & 3.6 & 3.0 & 3.1 & 3.5 \\
\hline Sust wrth*** & $4.2 \mathrm{a}$ & $3.5 \mathrm{~b}$ & $3.8 \mathrm{ab}$ & $3.7 \mathrm{ab}$ \\
\hline Profits* & $3.5 \mathrm{a}$ & $2.9 \mathrm{~b}$ & $3.4 \mathrm{ab}$ & $3.1 \mathrm{ab}$ \\
\hline Mngmt sust & 3.6 & 3.2 & 3.5 & 3.6 \\
\hline \multicolumn{5}{|l|}{ Obstacles } \\
\hline Uncertain & 5.2 & 5.3 & 5.6 & 4.6 \\
\hline Knowld envir & 4.5 & 4.9 & 5.3 & 3.7 \\
\hline Financial & 5.4 & 6.3 & 5.2 & 5.5 \\
\hline Compatible & 4.3 & 5.5 & 4.9 & 4.5 \\
\hline Unce prft & 4.8 & 6.3 & 6.2 & 5.9 \\
\hline Cash flow & 6.3 & 6.8 & 7.5 & 7.4 \\
\hline Cust sust*** & $3.2 \mathrm{~b}$ & $6.3 \mathrm{a}$ & $5.6 \mathrm{ab}$ & $4.2 \mathrm{ab}$ \\
\hline Incentive & 6.0 & 6.7 & 6.3 & 6.9 \\
\hline Loss & 5.1 & 6.1 & 6.2 & 5.2 \\
\hline
\end{tabular}

${ }^{2}$ Within-row means followed by different letters are significantly different by Tukey's honestly significant difference test at $P \leq 0.05$.

*Significant at the $P=0.10$ level, **significant at the $P=0.05$ level, ***significant at the $P=0.01$ level.

practice would not be compatible with their existing production systems. They also felt they had insufficient knowledge of the potential financial effects that converting to sustainable practices would have on their respective businesses.

Our results show that operation size and customer type may influence an operation's motivation for engaging in sustainable activ- were asked about their attitudes toward sustainability and the obstacles for implementing these practices. No significant differences were found based on sales, which is a measure of size. However, some attitudes and obstacles differed significantly based on the types of crops grown and how operations classified their business. Greenhouse only businesses were the only group that did not think energy use was a concern for their business. This is not surprising because $58 \%$ of greenhouse (floriculture) respondents indicated that they had already implemented conservation or efficiency energy measures in their operation in 2008 (Hall et al., 2009). Greenhouse/ nursery businesses disagreed with the statement that their state had stricter water restrictions than other states. Other green industry businesses had a moderate opinion on how customers value sustainable products compared with nursery only, greenhouse only, and greenhouse nursery businesses. These findings show that operations within the green industry have different concerns that may affect their perceived value of risk to implement sustainable production practices. Each segment of the industry will have different issues that will affect its perceived risk and ease of implementation for sustainability.

Of interest to all greenhouse and nursery firms and certification agencies is that none of the respondents in this survey were sustainably certified, but at least one-fourth $(25.8 \%)$ were interested in certification. The lack of certified firms could be the result of the size of the operations surveyed because past research has shown large greenhouse growers have more of an incentive to become certified sustainable (Hall et al., 2010b). Similarly, only $38 \%$ of floriculture producers were interested in certification in 2008 and over half had heard of Veriflora ${ }^{\circledR}$. This could also be the result of a desire to adopt practices, making better environmental choices without the need for additional time and expense of becoming certified until consumer demand heightens interest.

The extent to which firms of all sizes and producers of different types of plants adopt sustainable practices and/or become certified needs to be further investigated. We suggest that the present study has captured the initial adoption of sustainability.

\section{Literature Cited}

Berghage, R.D., E.F. Wheeler, and W.H. Zachritz. 1999. 'Green' water treatment for the green industries: Opportunities for biofiltration of greenhouse and nursery irrigation water and runoff with constructed wetlands. HortScience 34:50-54.

Botts, B. 2007. Beauty and the plastic beast. Chicago Tribune Online, 9 Oct. 2007. <http:// www.chicagotribune.com/news/local/nearwest/ chi0610plastic_jpjun10,1,5806552.story>.

Brooker, J.R., D. Eastwood, C. Hall, K. Morris, A. Hodges, and J. Haydu. 2005. Trade flows and, marketing practices within the U.S. nursery industry: 2003. Southern Coop. Series Bull. 404, Univ. of Tenn. Ag. Exp. Sta.

Cameron, A.C. 2009. Problems with plastic. Chron. Horticult. 49:8-10. 
Dillman, D.A. 2007. Mail and Internet surveys: The tailored design method. 2nd Ed. Wiley, Hoboken, NJ.

Evans, M.R. and D.L. Hensley. 2004. Plant growth in plastic, peat, and processed poultry feather fiber growing containers. HortScience 39:1012-1014.

Garthe, J.W. and P.D. Kowal. 1993. PennState fact sheet C-8. 10 Feb. 2010. <http://www.abe.psu. edu/extension/factsheets/c/C8.pdf $>$.

Hall, C.R., B.L. Campbell, B.K. Behe, C. Yue, R.G. Lopez, and J.H. Dennis. 2010a. The appeal of biodegradable packaging to floral consumers. HortScience 45:583-591.

Hall, C.R., A.W. Hodges, and J.J. Haydu. 2006. The economic impact of the green industry in the United States. HortTechnology 16:345-353.

Hall, T.J., J.H. Dennis, R.G. Lopez, and M.I. Marshall. 2009. Factors affecting growers' willingness to adopt sustainable floriculture practices. HortScience 44:1346-1351.

Hall, T.J., R.G. Lopez, M.I. Marshall, and J.H. Dennis. 2010b. Barriers to adopting sustainable floriculture certification. HortScience 45:778783.

Hodges, A.W., C.R. Hall, B.K. Behe, and J.H. Dennis. 2008. Regional analysis of the U.S nursery industry. HortScience 43:1807-1812.

Krug, B.A., S.E. Burnett, J.H. Dennis, and R.G. Lopez. 2008. Growers look at operating a sustainable greenhouse. GMPro 28:43-45.

Lifestyles of Health and Sustainability. 2009. 10 Feb. 2010. <http://www.lohas.com/>.

Lopez, R.G., S.E. Burnett, J.H. Dennis, and B.A. Krug. 2008. 8 steps to take to become sustainable. GMPro 28:26-29, 50.

Milieu Project Sierteelt. 2009.10 Feb. 2010. <http:// www.my-mps.com/>.

Richards, D.L. and D.W. Reed. 2004. New Guinea impatiens growth response and nutrient release from controlled-release fertilizer in a recirculating subirrigation and top-watering system. HortScience 39:280-286.

Stewart, A. 2007. Flower confidential: The good, the bad, and the beautiful in the business of flowers. Algonquin Books of Chapel Hill, Chapel Hill, NC.

U.S. Dept. of Agriculture. 2007. Floriculture and nursery crops yearbook: Report. Econ. Res. Service, Wash., D.C, 10 Feb. 2010. <http:// www.ers.usda.gov/Publications/Flo/2007/09Sep/ FLO2007.pdf $>$.

U.S. Dept. of Agriculture. 2009. Floriculture crops 2008 summary. 10 Feb. 2010. <http://usda. mannlib.cornell.edu/usda/current/FlorCrop/ FlorCrop-04-23-2009.pdf>.

U.S. Dept. of Agriculture National Ag. Statistics Service. 2007. Nursery crops 2006 summary. 10 Feb. 2010. <http://usda.mannlib.cornell.edu/ usda/current/NursProd/NursProd-09-26-2007. pdf $>$.

Veriflora. 2009. About the program. 10 Feb. 2010. $<$ http://www.veriflora.com/default.asp $>$.

Yue, C., C. Hall, B.K. Behe, B.L. Campbell, R.G. Lopez, and J.H. Dennis. 2010. The appeal of biodegradable packaging to floral consumers. J. Agr. Appl. Econ. (in press). 